\title{
Joining Forces for Public Value Creation? Exploring Collaborative Innovation in Smart City Initiatives
}

Oliver Neumann ${ }^{\mathrm{a} *}$, Christian Matt ${ }^{\mathrm{b}}$, Benedikt Simon Hitz-Gamper ${ }^{\mathrm{b}}$, Lisa

Schmidthuber ${ }^{\mathrm{c}}$ and Matthias Stürmer ${ }^{\mathrm{a}}$

${ }^{a}$ Research Center for Digital Sustainability, University of Bern, Bern, Switzerland; ${ }^{b}$ Institute of Information Systems, University of Bern, Bern, Switzerland; ' Institute for Public and Nonprofit Management, Johannes Kepler University, Linz, Austria

*Oliver Neumann, University of Bern, Research Center for Digital Sustainability,

Schützenmattstrasse 14, CH-3012 Bern, Switzerland,

E-Mail: oliver.neumann@iwi.unibe.ch, Phone: +41 767497260

Christian Matt, University of Bern, Institute of Information Systems,

Engehaldenstrasse 8, CH-3012 Bern, Switzerland

E-Mail: christian.matt@iwi.unibe.ch, Phone: +41 316314967

Benedikt Simon Hitz-Gamper, University of Bern, Institute of Information Systems,

Engehaldenstrasse 8, CH-3012 Bern, Switzerland

E-Mail: benedikt.hitz@iwi.unibe.ch, Phone: +41 316313371

Lisa Schmidthuber, Johannes Kepler University Linz, Institute of Public and Nonprofit Management, Altenberger Str. 69, AT-4040 Linz, Austria

E-Mail: lisa.schmidthuber@jku.at, Phone: +43 73224684405

Matthias Stürmer, University of Bern, Research Center for Digital Sustainability, Schützenmattstrasse 14, CH-3012 Bern, Switzerland

E-Mail: matthias.stuermer@inf.unibe.ch, Phone: +41 316313809 
Oliver Neumann is a postdoctoral researcher in the Research Center for Digital Sustainability at the University of Bern, Switzerland. He holds a doctorate in Business Administration and Management from the University of Bern. His research interests include digital transformation in government, public management, innovation, crowdsourcing, and open data.

Christian Matt is assistant professor in the Institute of Information Systems at the University of Bern, Switzerland. He holds a Ph.D. in Management from Ludwig-Maximilians-Universität (LMU) Munich, Germany. His current research focuses on corporate digital transformation and digital value creation, as well as on digital customer interfaces and experiences.

Benedikt Simon Hitz-Gamper is a doctoral researcher in the Institute of Information Systems at the University of Bern, Switzerland. His research interests are centred around open data in general and include innovation by means of open data, creation and use of open data, and the technical foundations supporting the open data life cycle.

Lisa Schmidthuber is a postdoctoral researcher in the Institute of Public and Nonprofit Management at Johannes Kepler University Linz, Austria. Her research interests include innovation management in the public and private sector focusing on value-creation by integrating citizens and customers in innovation processes.

Matthias Stürmer is head of the Research Center for Digital Sustainability at the University of Bern, Switzerland. With a lectureship on digital sustainability he teaches, researches and consults on the topics of open source software, open data, open government, smart cities, ICT procurement, and digital sustainability. 
Highlights of this study:

- Local governments often struggle with IT-enabled innovation in smart city initiatives

- In smart cities, the use of collaborative innovation approaches is growing

- Local governments benefit from the innovation assets of their collaboration partners

- In continental Europe, local governments often collaborate with utility companies

- Collaborations need to follow a stewardship logic to ensure public value creation 


\title{
Joining Forces for Public Value Creation? Exploring Collaborative Innovation in Smart City Initiatives
}

\author{
Creating public value is a key goal of public administrations, both in their daily \\ business and in the growing field of smart government and smart cities, which focuses \\ on IT-enabled innovations in the public sphere. However, many public administrations \\ still struggle with such innovations due to complex technologies, high investments, and \\ the numerous stakeholders involved. To address this issue, some local governments in \\ continental Europe have turned to collaborative innovation approaches, partnering with \\ (semi-)public utility companies in the hope that their additional innovation assets will \\ boost innovativeness. Nevertheless, it remains unclear how exactly such collaborations \\ should be governed to ensure that the focus remains on creating public value, as utility \\ companies may have their own agendas. To explore this question, we conducted a \\ comparative case study in the context of smart city initiatives with four cases in Swiss \\ local governments. Drawing on agency and stewardship theory, we then propose a \\ model of public-value-focused collaborative innovation, enabling us to explore various \\ collaboration characteristics and their effects on public value creation. Our findings \\ suggest that both agency- and stewardship-based collaborations increase \\ innovativeness. However, while agency collaborations tend to produce smart city \\ innovations that mainly serve the utility companies' business interests, stewardship \\ relationships lead to innovations that are focused more on public value creation. As \\ such, our study extends the literature on the effects of collaborative innovation on \\ public value, and it provides practical recommendations on how such collaborative \\ innovation should be designed.
}

Keywords: public value, smart city, collaborative innovation, local government, utility company, stewardship theory, agency theory, Switzerland

\section{Introduction}

The pursuit of public value creation is increasingly viewed as a core paradigm in public administration, guiding public action and laying the foundations for government legitimacy at all levels, federal, regional and local (Bryson, Crosby, \& Bloomberg, 2014; Cordella \& Bonina, 2012; Talbot, 2009). The concept of public value has been defined in many different ways, for instance as "what impacts on values about the "public"” (Meynhardt, 2009, p. 205), 
where values about the public can refer to different dimensions such as service quality, integrity, equal opportunities and citizen involvement (Jørgensen \& Bozeman, 2007; Meynhardt, 2009). Acknowledging the relative "fuzziness" of the concept and the many other definitions around (Bryson, Sancino, Benington, \& Sørensen, 2017; Talbot, 2009), for the sake of clarity and simplicity, this study uses the public value definition as laid out above. In recent years, a new avenue for public value creation has been identified in the growing field of IT-enabled innovations in the context of digital government (Cordella \& Bonina, 2012; Pang, Lee, \& DeLone, 2014; Soe \& Drechsler, 2018). This development is particularly prevalent in the literature on smart cities and smart government, as these concepts encompass at their core dimensions such as citizen centricity, innovation and technology savviness (Gil-Garcia, Zhang, \& Puron-Cid, 2016). It is especially the dimension of citizen centricity that is closely related to the concept of public value: "Citizen centricity is a key dimension characterizing smartness in government. It implies that governments know what citizens want and use ICTs to fulfil citizens' needs and provide personalized information and services" (Gil-Garcia et al., 2016, p. 527). At the same time, achieving smartness in government depends on IT-enabled innovations which, in turn, require profound knowledge of certain key technologies such as mobile phone services, artificial intelligence, wireless technologies, power grids, a multitude of different (IoT-)sensors, broadband, wide-area networks, data management and analytics and RFID tags (Kankanhalli, Charalabidis, \& Mellouli, 2019; Naphade, Banavar, Harrison, Paraszczak, \& Morris, 2011). For instance, in smart city initiatives, smart parking solutions, in which the interaction of sensors, apps and corresponding user interfaces ensures that citizens are better informed about free parking spaces, may allow local governments to improve public value aspects such as service quality and reliability (Meynhardt, 2009). Other examples of possible smart city services include air 
pollution control, citizen issue reporting, home crime prevention, and missing children prevention (for an encompassing list of services, see Lee \& Lee, 2014).

However, since the necessary knowledge of technologies is often not sufficiently available in governments, driving IT-enabled innovation internally is in many cases not a viable option. Additionally, to make such public-value-focused innovations work, different IT-devices and applications across several stakeholders need to work together, requiring not just profound technological skills, but also concerted efforts from local governments and other players, such as sensor manufacturers, parking providers, and app developers (Bryson et al., 2014; Sørensen \& Torfing, 2011). It further has to be noted that, failures in such complex, IT-enabled innovation projects may not only lead to high costs, but also to public administrations wasting resources that could have been used to leverage public value creation potential elsewhere. Considering this is important as the public sector faces particular challenges to succeed in complex innovations due to constraints from political decisionmaking (Koppenjan \& Klijn, 2004), long-time horizons of investments, comparatively small innovation budgets (Borins, 2001), and a culture of risk aversion and resistance to change (De Vries, Bekkers, \& Tummers, 2016; Feiock, Lee, Park, \& Lee, 2010; Mulgan \& Albury, 2003).

To address these challenges and to drive IT-enabled innovation in smart government initiatives, public administrations increasingly collaborate with public, non-profit and private actors. Such joint innovation programmes have been termed "collaborative innovation" (Hartley, Sørensen, \& Torfing, 2013; Sørensen \& Torfing, 2011; Torfing, 2019), defined as "multi-actor collaboration that [...] may foster innovation by bringing together public and private actors with relevant innovation assets, facilitating knowledge sharing and transformative learning, and building joint ownership to new innovative visions and practices” (Sørensen \& Torfing, 2012, p. 1). The innovation assets held by partnering actors 
may include experience, knowledge about new technologies, creativity, or budget (Crosby, ' $t$ Hart, \& Torfing, 2017), so that the problem-solving capacities and innovativeness of the involved public administration are enhanced through the collaboration. Collaborative innovation is thus, at least in the context of the public sector, often seen as a "superior innovation driver" (Torfing, 2019, p. 1).

However, it should not be overlooked that cooperation partners may have interests of their own and the administrations' goal to create public value through IT-enabled innovation may not necessarily be coherent with them (Klievink, Bharosa, \& Tan, 2016). Public and semi-public utility companies, which will be at the fore in this study, like any other company tend to primarily strive to create private business value in the form of revenue and profits (Moore, 1995, p. 35), which illustrates the potential for a conflict of interest in such collaborative innovation. Therefore, it is essential to investigate the results of collaborative innovation with regard to the creation of public value in more detail.

Previous research has stressed that the relationship between IT resources and public value creation is mediated by capabilities such as public service delivery, public engagement, co-production, resource-building, and public-sector innovation capability, and that these capabilities are important levers for public managers to stimulate public value creation (Pang et al., 2014). However, empirical evidence on the aspects of innovation and coproduction/collaboration from a public value perspective is still scarce. Hence, a first important gap in the literature that we address is whether collaborative innovation can contribute to the creation of public value as one of the principal aims of public administration (Meynhardt, 2009; Moore, 1995) or rather leads to increasing business value. A second important gap that we seek to close is how such collaborative innovation should be designed and governed for increasing innovativeness while ensuring that the focus is on public value creation. 
To address the aforementioned research gaps, we conduct a case-based analysis in the context of smart city initiatives in local governments. Many local governments have started turning to public and semi-public utility companies, which are primarily responsible for providing natural monopoly services such as water, gas, electricity and telecommunications services, as partners in collaborative innovation in their smart city programmes. This development is particularly evident in continental Europe, where utility companies are often at least partially owned by the municipalities, meaning that utilities in these countries are state-owned enterprises (SOEs) and usually have strong relationships with the respective local governments (OECD, 2017) compared to their often privatised counterparts in the UK or the US. And although such utility companies are often still quite closely integrated with the local governments, more flexible regulation has led them to resembling private sector organisations regarding their organisational structures and processes, improving both their innovativeness and competitiveness (Vogelsang, 2002).

Not only owing to their extensive presence in many central European markets, we hold that analysing collaborative innovation between public and semi-public utility companies and local governments is of high interest for practice and research alike. It is also the particular nature of utility companies as often SOEs that makes such an analysis particularly appealing in the context of public value creation. We focus intentionally on the local level of government where the interaction between public administration and its users is the most direct (Benington, 2009) and public value creation is more tangible than at higher administrative levels. Based on our theoretical model, which draws on agency theory (Jensen \& Meckling, 1976; Ross, 1973) and stewardship theory (Davis, Schoorman, \& Donaldson, 1997), we conducted a comparative case study involving four cases where local governments in Switzerland use different approaches to collaborative innovation with a utility company in the context of smart city initiatives. 
In all, by analysing the effects of different types of collaborative innovation in the public sector, this study contributes to the literature on public value creation when multiple stakeholders are involved (Bryson et al., 2017; Hartley, Alford, Knies, \& Douglas, 2017; Page, Stone, Bryson, \& Crosby, 2015). Cordella and Bonina (2012) underline the importance of analysing the effects of the public sector's IT adoption on social and political dimensions rather than applying private sector frameworks with a focus on achieving only better financial outcomes. The public value paradigm serves as an ideal theoretical framework for investigating the outcomes of collaborative innovation, as the framework takes both the complexity of implementing IT-enabled innovation (Cordella \& Bonina, 2012) and public sector-specific goals in the smart city context into account. By illustrating how such collaborative innovation setups are designed in practice, we also contribute to the literature on collaborative innovation in the public sector (Hartley et al., 2013; Sørensen \& Torfing, 2011; Torfing, 2019), adding to recent research that links collaborative innovation to public value governance (Crosby et al., 2017). Additionally, we provide actionable recommendations for practitioners in local public administration on how to optimise their collaborative innovation approaches in order to enhance public value creation. Our contribution is timely as many local governments are currently engaging in IT-enabled innovation endeavours in the context of smart city programmes (e.g. Gil-Garcia, Helbig, \& Ojo, 2014; Meijer \& Bolívar, 2016).

\section{Theoretical Foundations}

\subsection{Public Value Creation through Collaborative Innovation}

One of the key goals of public sector organisations is the creation of public value, which means that public managers are "explorers commissioned by society to search for public value" (Moore, 1995, p. 299). Bryson et al. (2014, p. 448) understand public value as 
"producing what is either valued by the public, is good for the public [...], or both, as assessed against various public value criteria”. Benington and Moore (2010) point out that public value means "first, what the public values", focusing on "individual interests [...] of current users" and, "second, what adds value to the public sphere", focusing "on the longer term public good, including the needs of generations to come" in a collectively shared view of a good and just society (Geuijen, Moore, Cederquist, Ronning, \& van Twist, 2017). In this study, we draw on Meynhardt (2009, p. 205) who offers a more tangible definition and conceptualisation of public value: "Public value is what impacts on values about the 'public"'. The said values, in turn, may refer to one or more of the four commonly used public value dimensions: moral-ethical (e.g. integrity, human dignity), hedonistic-esthetical (e.g. service quality, reliability), political-social (e.g. citizen involvement, compromise), or utilitarian-instrumental (e.g. openness, sustainability). Public value is, of course, not static or inherent but arises through activities such as public service delivery (see e.g. Hartley et al., 2017; Moore, 1995). As such, a particularly promising avenue for public value creation is innovation in regard to the products and services which public administrations offer to citizens (Bommert, 2010; Cordella, 2007; Hartley, 2005; Pang et al., 2014). Hartley (2005, p. 30) even argues that "in public services [...] innovation is justifiable only where it increases public value in the quality, efficiency or fitness for purpose of governance or services." This notion of public sector innovation is also inherent in the concept of smart cities, "which deals with innovation (not necessarily but mainly ICT-based) in the urban space that aims to enhance the 6 city dimensions (people, economy, government, mobility, living and environment)" (Anthopoulos, Janssen, \& Weerakkody, 2016, p. 89). All of the six mentioned dimensions may be understood as contributions to public value creation.

However, especially in the context of IT-enabled innovations which are often the basis for smart city initiatives, the innovativeness of public administrations is impeded by at 
least four important factors (Borins, 2001; Sørensen \& Torfing, 2011). First, adherence to legal and bureaucratic rules is a key principle in government organisations, which often means that the consequences of failed innovations are grave. This in turn leads to high-risk aversion among politicians and public employees, which is detrimental to innovation. Second, there is a lack of competition, economic incentives and venture capital in the public sector confining innovativeness. Third, the complexity of public services tends to be high due to political and legal obligations and the multitude of stakeholders, which governments have to take into account, making change and innovation difficult. Innovation in the public sector often follows complex multi-step processes requiring stringent management efforts to succeed (Wonglimpiyarat \& Yuberk, 2005). Fourth, and of particular relevance in IT-enabled innovation, local governments frequently lack personnel with sufficient knowledge of the latest technological developments and innovations. This last issue is further aggravated by the not-so-innovative image of most public organisations, leading innovative individuals to selfselect into the private sector. It is important to note, however, that some of the described features of governments hindering innovation are in place for a reason, and some of them even directly create public value, for instance in the dimensions of equal opportunities (Cordella, 2007; Cordella \& Willcocks, 2010). Nevertheless, a certain amount of innovativeness is still desired. Borins (2001, p. 311) describes this dilemma as follows: "In all likelihood, we as a society do not want the public sector to be as innovative as the private sector, nor to display the volatility of Internet start-ups. Yet it is equally likely that we want the public sector to be more innovative than it traditionally has been".

Collaborative innovation has been suggested as one possible approach to overcome the dilemma described above, helping public organisations to create public value through innovation by combining resources, sharing knowledge, and making use of innovation assets of partners (Soe \& Drechsler, 2018; Sørensen \& Torfing, 2011; Torfing, 2019). This is also 
reflected in the following definition, where collaborative innovation is understood as "multiactor collaboration that $[\ldots]$ may foster innovation by bringing together public and private actors with relevant innovation assets, facilitating knowledge sharing and transformative learning, and building joint ownership to new innovative visions and practices" (Sørensen \& Torfing, 2012, p. 1). As such, public value need not be created by a single public organisation independently but can be created in an orchestrated collaboration with other public or private organisations (Crosby et al., 2017), which is a shift from pure in-house production to a joined-up production mode (Cordella \& Paletti, 2018).

However, it has to be noted that despite the various benefits associated with collaborative efforts, collaborations in the context of local public administration may also fail to deliver public value (Barringer \& Harrison, 2000). Reasons for failure of interorganisational collaboration include, for example, the challenge of combining different organisational cultures and divergent expectations concerning value creation (Bryson et al., 2017). If multiple stakeholders are involved in public value creation through collaborative innovation, one has to consider that "different individuals and groups in society hold different views about which conditions in their societies should be viewed as public problems to be solved by government action, and what particular actions should be taken by the government to address the problems" (Geuijen et al., 2017, p. 629). It is especially the configuration of the collaboration between governments and their partners in IT-enabled innovation that we hold to be important for the innovation outcome and whether public value is created or not. However, to date, empirical research investigating how collaborative innovation needs to be designed in the context of IT-enabled innovations from a public value perspective is still scarce (see also Cordella \& Bonina, 2012), although the research interest on the public value of IT-enabled projects in the smart city and e-government context is growing (Twizeyimana \& Andersson, 2019). Specifically, there is a lack of both comparative case studies on public 
value in this context, and empirical research on questions related to the creation of public value (Klievink et al., 2016; Twizeyimana \& Andersson, 2019). In the following, we address these gaps in research, drawing upon agency and stewardship theory to develop a model that describes different forms of collaborative and IT-enabled innovation and their impact on public value creation. Moreover, we empirically illustrate the model based on a comparative case study involving four cases in Swiss local governments.

\subsection{Agency Theory and Stewardship Theory}

Agency and stewardship theories are particularly suited for analysing collaborative innovation setups since they allow us to scrutinise the interplay between frequently less innovative actors, such as local governments, and potentially more innovative actors, such as utility companies. Agency and stewardship theories have in common that both refer to the relationship between two parties: principals, who seek partners to support them in certain activities which promote their mission or interest (such as driving innovation), and agents, respectively stewards to perform the desired activities on their behalf or cooperate with them (Davis et al., 1997). However, there are also some notable differences between agency theory and stewardship theory, which we will discuss next:

Agency theory (Jensen \& Meckling, 1976; Ross, 1973) assumes that actors are rational, self-serving economic beings seeking to maximise their individual utility. This holds for both agents and principals, whose relationship is usually based on a contract where the agent carries out certain duties on the principal's behalf and receives a reward in return. Financial incentives and monitoring instruments are used to ensure that the agent will act in the principal's interest. This is because the agent's and the principal's interests usually diverge and there is a lack of trust (Van Slyke, 2006). However, such incentives and monitoring measures may often not be very effective, for instance if agents have an 
informational advantage over the principal regarding the tasks they perform on their behalf and their respective outcomes (Davis et al., 1997), when the agent's contributions are difficult to measure, which is often a problem in the public sector, or if agents are already committed to the goals of the principal (Cordella \& Cordella, 2017). Notwithstanding the theoretical complexities and conjectures surrounding agency theory (Davis et al., 1997; Eisenhardt, 1989), for the purpose of our discussion, we rely on this basic understanding of agency theory.

Stewardship theory responds to the shortcomings of agency theory and agency-based collaborations by studying "situations in which executives as stewards are motivated to act in the best interests of their principals" (Donaldson \& Davis, 1991). In contrast to agency collaborations, the interests and actions of stewards are aligned with the interests of their principals (Davis et al., 1997). Stewards are assumed to act for the benefit of the principal because they value the utility drawn from such behaviour and working towards a larger purpose as higher than the utility gained from self-serving behaviour (Davis et al., 1997). As Block (2013, p. 16) puts it, "stewardship begins with the willingness to be accountable for some larger body than ourselves". In contrast to agency theory, governance mechanisms and extrinsic incentives are not necessary to align the steward's behaviour with the principal's interests. Instead, "stewards are motivated to behave in ways that are consistent with organisational objectives" (Davis et al., 1997, p. 25) and control mechanisms may even diminish the motivation of stewards (Argyris, 1972; Frey \& Jegen, 2001). As such, stewardship theory promotes organisational structures that facilitate and empower the work of individual actors, whereas agency theory favours monitoring and control (Davis et al., 1997). Across several disciplines and contexts, the stewardship perspective has been used to complement agency theory, e.g. to explore the relationship between venture capitalists' and entrepreneurs (Arthurs \& Busenitz, 2003), between public administrators and non-profit 
organisations (Van Slyke, 2006), or among family members in family businesses (Corbetta \& Salvato, 2004; Eddleston \& Kellermanns, 2007). In addition, Van Slyke (2006) found that principal-agent relationships usually evolve into principal-steward relationships over time as trust between the actors increases, suggesting that the two theories are closely intertwined and should be used in conjunction.

Stewardship attitudes are assumed to be especially prevalent in public organisations, where the promotion of the public interest and the creation of public value are key organisational goals (Bryson et al., 2014). For instance, public employees are often interested in serving the public interest, hold high levels of organisational commitment, and identify themselves with organisational activities and missions (Pandey \& Stazyk, 2008; Ritz, Brewer, \& Neumann, 2016), as opposed to purely pursuing self-interest. As such, public employees may be regarded as stewards of a rather vaguely defined principal: the public at large, represented by government organisations and institutions. However, government workers are not the only possible stewards in this context, as other non-public or semi-public organisations may also contribute to the pursuit of government goals, be it as stewards or agents (Van Slyke, 2006) - for instance in collaborative innovation.

\subsection{A Conceptual Model of Collaborative Innovation and Public Value Creation}

While collaborative innovation between (local) governments and innovation partners that hold additional innovation-related resources seems like a promising way to increase the general innovativeness of public administration, the need to identify and develop adequate collaboration and governance procedures for such innovations to succeed has been stressed repeatedly (Kankanhalli, Zuiderwijk, \& Tayi, 2017; Scupola \& Zanfei, 2016; Sørensen \& Torfing, 2017). As the creation of public value is key in public sector innovation and smart city initiatives, it is of paramount importance that attention is paid to the goals that are to be 
achieved through innovation. In the case of collaborative innovation between governments and innovation partners, it thus has to be considered that innovation partners often strive to create business value such as revenue and profits for their own business, as opposed to public value. Against this backdrop, more knowledge is needed about how collaborative innovation between governments and innovation partners should be designed and governed to ensure that the focus is on creating public value instead of just business value (also referred to as private value).

This distinction of those two types of value creation is in line with Cordella and Bonina (2012, p. 516), who point out "that public sector strategies differ from private sector strategies because the former are driven by the overriding goal of creating public value, while the latter are aimed at creating private value". In addition, even though in continental Europe, many utility companies, which are the focus of this study, are only semi-private or even still public, they still operate in a market environment, resembling private sector companies. Therefore, while the interests of the government and the innovation partner should ideally be the same, this will often not be the case, highlighting the need to design cooperation in a way that ensures the interests of the government remain at the fore. In light of the above discussion on agency and stewardship theory, we assume that the mode of the relationship between governments and innovation partners is crucial to achieve public value creation in collaborative innovation, as it allows for a trustful and voluntary alignment of interests between the principal (the government) and the steward (the innovation partner).

For our conceptual model, we apply agency theory and stewardship theory as the key modes to describe the relationship between governments and innovation partners. We expect that, while both modes generally lead to higher innovativeness because of the combination of innovation assets, each of the two relationship modes will lead to different types of value creation. More specifically, as illustrated in Figure 1, if the relationship between a 
government (principal) and an innovation partner (agent) is a relationship in which the principal gives an innovation mandate to and controls the actions of the agent, we expect the agent to still mostly pursue its self-interest. At the same time, the agent will likely use its informational advantage to render monitoring difficult to impossible. Consequently, an agency-type relationship will tend to produce innovation-related outcomes geared mostly towards creating business value for the innovation partner rather than public value. In contrast, if the relationship is of the stewardship type based on mutual trust and empowerment, we assume that the government (principal) as well as the innovation partner (steward) will be stimulated by motives beyond self-interest. As a result, they will jointly aim at contributing to the principal's key mission, which is promoting the public interest and creating public value. However, this should not necessarily prevent the innovation partner from also pursuing other goals such as creating business value as a result of the collaborative innovation. As such, we assume that only a stewardship mode of collaborative innovation will be compatible with the definition of public sector innovation by Daglio, Gerson, and Kitchen (2015, p. 4), who stress that "public sector innovation is about new ideas that work at creating public value". According to these authors, besides novelty and implementation, which are features of any type of innovation, public sector innovation additionally requires an impact on public results, efficiency and effectiveness of public service delivery, and an orientation towards citizen satisfaction, which we predict will be enabled through a stewardship-type collaborative innovation.

To summarise, we expect stewardship relationships in collaborative innovation between public administrations and innovation partners to create innovation-related outcomes geared towards both public value and business value, which in the context of IT-enabled innovations in smart city initiatives is more desirable than innovation-related outcomes aligned with business value creation only. In the following, we will analyse four case studies 
of local governments in Switzerland pursuing collaborative innovation approaches with utility companies as innovation partners to illustrate our model. Besides determining the types of value creation, we will also analyse the effects of the approaches chosen on the level of overall innovativeness.

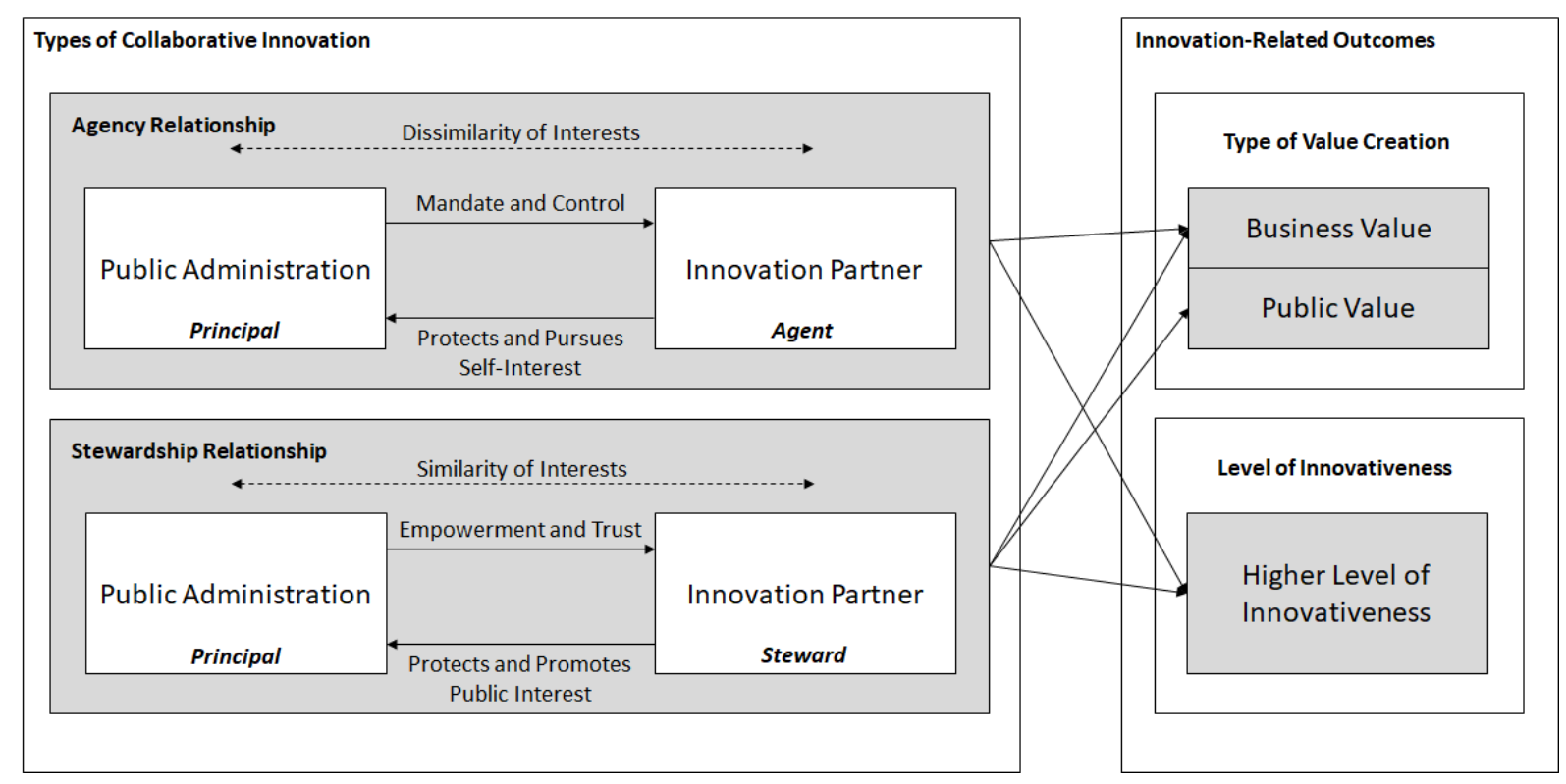

Figure 1. Types of collaborative innovation and innovation-related outcomes.

\section{Methods}

\subsection{Case Selection and Data Collection}

As outlined in the introduction, the specific context in which we explored our research question is collaborative innovation between local governments and public and semi-public utility companies in smart city initiatives in Switzerland. Much like other organisations such as living labs (Gascó, 2017), utility companies can serve as innovation intermediaries between governments and citizens. Since in continental Europe, many utility companies are (partially) SOEs, they usually have close ties with local governments and better knowledge of technological developments, given the rather technical nature of their business. This oftentimes makes them suitable partners in collaborative innovation for local governments, especially in the smart city context. Additionally, utility companies are usually less 
constrained by innovation-inhibiting factors than a public administration. For instance, utility companies are exposed to a certain degree of market pressure, which helps to improve the joint innovativeness in collaborative innovation with the public sector (Hartley et al., 2013).

We used an exploratory multiple case study research approach and investigated innovation activities in the context of smart city initiatives of four utility companies in three major cities in Switzerland. These cases were not randomly sampled but purposefully selected because we identified them as most suitable to help us understand the problem and analyse the research questions (Creswell \& Creswell, 2018; King, Keohane, \& Verba, 1994). The suitability of the chosen cases grounds in a publicly known track record of innovation projects allowing us to study innovation undertakings with various outcomes. Such theoretical sampling allows illuminating and extending relationships among constructs (Eisenhardt \& Graebner, 2007), increasing robustness and methodological rigor when choosing a multiple-case study approach (Eisenhardt, 1991).

Based on the central elements of the different types of collaboration and innovationrelated outcomes, we developed a semi-structured interview guideline to obtain explorative insights into the collaborative innovation between local governments and utility companies. This approach allows in-depth descriptions of social phenomena thus helping us to understand the underlying causal relationships (Yin, 2018). In total, we conducted 15 indepth interviews with key senior decision makers from the local governments and managers of the utility companies (Appendix 1). All of them are knowledgeable experts who are able to provide diverse perspectives on the focal phenomena (Eisenhardt \& Graebner, 2007). In the governments, we interviewed the politician or the secretary general involved in the strategic steering committee of the utility company (e.g. board of directors). In addition, we interviewed the government official in charge of the smart city strategy and the activities of the city (town clerk, head of economic development, Chief Digital Officer). Within the utility 
companies, we interviewed the Chief Executive Officer (CEO) as well as the managers responsible for innovation and the smart city projects. By choosing senior professionals from higher hierarchy levels, we ensured that our interviewees were able to represent not only a particular and personal point of view, but also a comprehensive view of the matter.

The interviews took one hour on average and were conducted between October and December 2017 at the workplace of the interviewees. We followed a semi-structured interview guideline consisting of four sections. The main section was derived from our theoretical model (see Figure 1). It focused on the particular relation between local government, the utility company and the type of innovation value creation asking questions like "in which domains do the interests of the different actors overlap and in which do they diverge?" or "to what extent does the utility company pursue its own commercial activities?" The other sections addressed questions like "is there an innovation assignment by the local government to the utility company?" and "how is the success of innovation measured, which instruments exist?" In addition, more open and explorative questions were included, giving our interview partners the possibility to bring further topics to our awareness. Each interview was conducted by two members of the research team. For consistency, we ensured that one of the authors participated in each of the 15 interviews. We used the possibility of having more than one interviewee per utility company and local government to cross-check the answers given by interviewees of the same utility company or local government.

\subsection{Case Descriptions}

The selected Swiss cities are of representative size (75,000 to 390,000 inhabitants) for many European municipalities (Table 1). All three cities have one or two utility companies that innovate through various initiatives such as smart city projects, Internet of Things pilot programmes and other IT-enabled activities. Such innovation activities are typical for many 
of today's utility companies owning large water, sewage, electricity and gas supply infrastructures for many decades and having started to invest in fiber optics in the past 10 years (Shumate, 2008). Needing to develop innovative services and products to help exploit their expensive communication infrastructure, utility companies often start new smart cityrelated projects within their municipality. Nevertheless, the utility companies remain at least partially under public control, limiting their strategic and operative flexibility.

Among the four analysed cases presented in Table 1, Utility Companies B and D are fully public since they are organised as departments of the local public administration and operate under public law. Utility Companies A and C, in contrast, are only semi-public, being partially or fully owned by the local governments but legally and organisationally independent from them. A and D operate a broad range of networks offering services based on electricity, water, gas, heating and fiber optics. B only operates an electricity and fiber optic network whereas $\mathrm{C}$ offers services based on gas supply. The information gathered about the individual cases, as displayed in Table 1, originates from both publicly available sources such as annual reports, company and government websites as well as from public news coverage.

\begin{tabular}{|l|l|l|l|l|}
\hline & Case A & Case B & Case C & Case D \\
\hline Utility Company & A & B & C & D \\
\hline City & I & II & II & III \\
\hline $\begin{array}{l}\text { Networks } \\
\text { Eperated } \\
\text { water, gas, } \\
\text { heating, fiber } \\
\text { optics }\end{array}$ & $\begin{array}{l}\text { Electricity, } \\
\text { fiber optics }\end{array}$ & Gas & $\begin{array}{l}\text { Electricity, } \\
\text { water, gas, } \\
\text { heating, fiber } \\
\text { optics }\end{array}$ \\
\hline Annual revenue & $\begin{array}{l}+420 \mathrm{~m} \text { USD } \\
+900 \mathrm{~m} \text { USD }\end{array}$ & $+450 \mathrm{~m}$ USD & $+210 \mathrm{~m}$ USD \\
\hline
\end{tabular}




\begin{tabular}{|l|l|l|l|l|}
\hline Employees & $\begin{array}{l}+600 \\
\text { employees }\end{array}$ & $\begin{array}{l}+1100 \\
\text { employees }\end{array}$ & $\begin{array}{l}+210 \\
\text { employees }\end{array}$ & +280 employees \\
\hline $\begin{array}{l}\text { Organisational } \\
\text { independence of } \\
\text { utility company }\end{array}$ & $\begin{array}{l}\text { Independent, } \\
\text { owned by the } \\
\text { city }\end{array}$ & $\begin{array}{l}\text { Part of public } \\
\text { administration }\end{array}$ & $\begin{array}{l}\text { Independent, } \\
\text { majority } \\
\text { owned by the } \\
\text { city }\end{array}$ & $\begin{array}{l}\text { Part of public } \\
\text { administration }\end{array}$ \\
\hline $\begin{array}{l}\text { Example of smart } \\
\text { city innovations/ } \\
\text { technologies }\end{array}$ & $\begin{array}{l}\text { Citizen } \\
\text { information } \\
\text { and feedback } \\
\text { application }\end{array}$ & $\begin{array}{l}\text { Public low- } \\
\text { power wide- } \\
\text { area network; } \\
\text { smart parking } \\
\text { application }\end{array}$ & $\begin{array}{l}\text { No projects } \\
\text { with explicit } \\
\text { public value } \\
\text { focus }\end{array}$ & $\begin{array}{l}\text { Citizen } \\
\text { information and } \\
\text { exchange } \\
\text { platform; smart } \\
\text { power } \\
\text { management } \\
\text { solution }\end{array}$ \\
\hline
\end{tabular}

Table 1. Characteristics of the four utility companies (derived from their annual reports).

In the following, for each of the four cases, representative examples of the specific types of IT-enabled innovations that have resulted from the respective collaborative innovation activities in the local smart city context are given. Case A includes a smart city web and mobile application that provides data to the public, which is collected by the utility company anyway, like webcam pictures of various city locations and temperature and flow data of the local rivers. Another example is the development of a web and mobile application that allows citizens to report defects of various infrastructures within the city in a central place. Case B includes the deployment of a low-power wide-area network (LPWAN) within the city by the utility company. Using this LPWAN, another collaborative innovation is the development of a smart parking solution. A further project includes the preparation for future electric mobility applications. Case $\mathrm{C}$ is notable in that the innovation collaboration with regards to IT-enabled innovation from side of the utility company is mostly focused on other privately owned businesses related to the utility companies present and envisaged core business and not so much on creating public value. Finally, case D includes a smart city mobile application that intends to promote communication between different districts. In addition, in a newly 
built model neighbourhood, the innovation collaboration led to an intelligent energy control reducing the environmental impact and improving comfort. Furthermore, the utility company is building a "Smartnet" to connect various sensors and actuators within the city. Another example of innovation collaboration is a project for future electric mobility.

\subsection{Data Coding and Analytical Method}

All interviews were recorded and transcribed verbatim. We developed the coding schema following the deductive category assignment method (Mayring, 2014). We thus operationalised the constructs of our theoretical model into specific perspectives and attributes and applied them to the interview transcripts using the qualitative data analysis software MAXQDA (Kuckartz, 2014). The relevant perspectives for our theoretical model comprised the role of the utility company, its relationship with the government, and the innovation-related outcomes. The coding schema of the perspectives and attributes was refined during the coding process by merging sub-attributes into main attributes (Mayring, 2014). In total, we ended up with 16 codes and 287 codings related to our theoretical model. In accordance with recommendations by Ospina, Esteve, and Lee (2018) on transparency of qualitative data analysis and interpretation, we illustrate the perspectives and their related attributes in Table 2.

\begin{tabular}{|l|l|l|l|}
\hline Perspective & Attributes & Source & Example Coding \\
\hline $\begin{array}{l}\text { Role of utility } \\
\text { company }\end{array}$ & $\begin{array}{l}\text { Identification with } \\
\text { city }\end{array}$ & $\begin{array}{l}\text { Code } \\
\text { "Identification" }\end{array}$ & $\begin{array}{l}\text { CEO of Utility Company A: } \\
\text { "We translated our new } \\
\text { company website into the } \\
\text { local dialect." }\end{array}$ \\
\cline { 2 - 4 } & Trust by citizens & Code "Trust" & $\begin{array}{l}\text { CEO of Utility Company D: } \\
\text { "The utility company belongs } \\
\text { to the citizens. Therefore, they } \\
\text { trust the company." }\end{array}$ \\
\hline
\end{tabular}




\begin{tabular}{|c|c|c|c|}
\hline & Pressure to innovate & $\begin{array}{l}\text { Code "Innovation } \\
\text { Incentive" }\end{array}$ & $\begin{array}{l}\text { CEO of Utility Company B: } \\
\text { "We see tremendous change; } \\
\text { [...] we could lose our } \\
\text { traditional role." }\end{array}$ \\
\hline & $\begin{array}{l}\text { Innovation } \\
\text { department }\end{array}$ & $\begin{array}{l}\text { Code "Innovation } \\
\text { Competence" }\end{array}$ & $\begin{array}{l}\text { Head of the office for } \\
\text { economic development of } \\
\text { City II: "The utility company } \\
\text { has a department with } \\
\text { employees hired for } \\
\text { innovation." }\end{array}$ \\
\hline & $\begin{array}{l}\text { Key actors } \\
\text { of innovation }\end{array}$ & Code "Key Player" & $\begin{array}{l}\text { CEO of Utility Company D: } \\
\text { "The government has } \\
\text { commissioned the utility } \\
\text { company to bundle these } \\
\text { topics with the innovation } \\
\text { delegate XY": }\end{array}$ \\
\hline & Business agility & Code "Agility" & $\begin{array}{l}\text { Head of marketing and sales } \\
\text { of Utility Company A: "More } \\
\text { prototypes, more pilot- } \\
\text { customers and if it works out, } \\
\text { roll it out on a larger scale." }\end{array}$ \\
\hline & $\begin{array}{l}\text { Error management } \\
\text { culture }\end{array}$ & $\begin{array}{l}\text { Code "Error } \\
\text { Culture" }\end{array}$ & $\begin{array}{l}\text { CEO of Utility Company A: } \\
\text { "It has to be possible to try } \\
\text { things out and let them die if } \\
\text { they don't work out well." }\end{array}$ \\
\hline $\begin{array}{l}\text { Relationship } \\
\text { with local } \\
\text { government }\end{array}$ & $\begin{array}{l}\text { Smart city strategy of } \\
\text { local government }\end{array}$ & Code "Smart City" & $\begin{array}{l}\text { CEO of Utility Company B: } \\
\text { "There is a political } \\
\text { assignment to develop a smart } \\
\text { city strategy." }\end{array}$ \\
\hline & $\begin{array}{l}\text { Type of assignment } \\
\text { mandate }\end{array}$ & $\begin{array}{l}\text { Code "Assignment } \\
\text { Mandate" }\end{array}$ & $\begin{array}{l}\text { CEO of Utility Company B: } \\
\text { "The assignment to contribute } \\
\text { to smart city solutions must } \\
\text { come from the parliament or } \\
\text { the citizens." }\end{array}$ \\
\hline & Innovation mandate & $\begin{array}{l}\text { Code "Innovation } \\
\text { Mandate" }\end{array}$ & $\begin{array}{l}\text { Head of marketing and sales } \\
\text { of Utility Company A: } \\
\text { "We've wanted to get such a } \\
\text { mandate for quite a long } \\
\text { time." }\end{array}$ \\
\hline
\end{tabular}




\begin{tabular}{|c|c|c|c|}
\hline & $\begin{array}{l}\text { Dependence of utility } \\
\text { company on political } \\
\text { processes }\end{array}$ & $\begin{array}{l}\text { Code "Political } \\
\text { Dependence" }\end{array}$ & $\begin{array}{l}\text { CEO of Utility Company B: } \\
\text { "Whenever we have to } \\
\text { involve the parliament, the } \\
\text { project will be delayed by at } \\
\text { least half a year." }\end{array}$ \\
\hline & $\begin{array}{l}\text { Key local } \\
\text { government actor for } \\
\text { relation with utility } \\
\text { company }\end{array}$ & Code "Key Player" & $\begin{array}{l}\text { Member of the city executive } \\
\text { government of City I: "We } \\
\text { need someone to pull all the } \\
\text { strings and we have provided } \\
\text { resources for such a position." }\end{array}$ \\
\hline & $\begin{array}{l}\text { Communication } \\
\text { between local } \\
\text { government and } \\
\text { utility company }\end{array}$ & $\begin{array}{l}\text { Code } \\
\text { "Communication", }\end{array}$ & $\begin{array}{l}\text { Head of telecom unit of } \\
\text { Utility Company B: "Our } \\
\text { company gives lectures within } \\
\text { the local government [about } \\
\text { the technological } \\
\text { possibilities]." }\end{array}$ \\
\hline & $\begin{array}{l}\text { Common } \\
\text { understanding of } \\
\text { innovation }\end{array}$ & $\begin{array}{l}\text { Code "Common } \\
\text { Understanding" }\end{array}$ & $\begin{array}{l}\text { CEO of Utility Company A: } \\
\text { "The problem is: we would } \\
\text { have to develop a common } \\
\text { self-understanding in the } \\
\text { city." }\end{array}$ \\
\hline & $\begin{array}{l}\text { Alignment of } \\
\text { strategies and } \\
\text { structures }\end{array}$ & Code "Alignment" & $\begin{array}{l}\text { CEO of Utility Company A: } \\
\text { "The politicians want exactly } \\
\text { the opposite }[. . .] \text { but we really } \\
\text { do not want that!" }\end{array}$ \\
\hline $\begin{array}{l}\text { Innovation- } \\
\text { related } \\
\text { outcome }\end{array}$ & $\begin{array}{l}\text { Type of value } \\
\text { creation }\end{array}$ & $\begin{array}{l}\text { Code "Value } \\
\text { Creation" }\end{array}$ & $\begin{array}{l}\text { Head of marketing and sales } \\
\text { of Utility Company A: "The } \\
\text { benefit for the citizens is still } \\
\text { limited at the moment." }\end{array}$ \\
\hline & $\begin{array}{l}\text { Level of } \\
\text { Innovativeness }\end{array}$ & $\begin{array}{l}\text { Code } \\
\text { "Innovativeness" }\end{array}$ & $\begin{array}{l}\text { Head of corporate } \\
\text { development of Utility } \\
\text { Company C: "Our team can } \\
\text { quickly react to [changing] } \\
\text { customer needs." }\end{array}$ \\
\hline
\end{tabular}

Table 2. Coding schema for the data analysis. 


\section{Results}

\subsection{Role of the Utility Companies}

Upon exploring the specific role of the individual utility companies, we wanted to know if they identify themselves with their cities, thus feeling a special obligation towards them. Such an identification would set the utility companies apart from other external actors in the market. An identification with the city was found in the cases of A, B and D. Utility Companies B and D, which are part of the local government, have a special connection owing to their organisational placement. We also found that the employees of these companies are proud to be a part of their cities. Company A, which is characterised by a higher organisational independence, nevertheless identifies itself with the city. It even translated its webpage into the quite distinct local dialect to show its commitment. This identification was also confirmed by the town clerk of City I, stating: "In working together with our utility company, we realise that it feels a special responsibility towards the city." The case of Utility Company $\mathrm{C}$ is different, since the geographical focus of its activities goes beyond the city limits. Consequently, it does not identify itself particularly with the city. This was pointed out by the head of corporate development at Utility Company C: "We see ourselves as a countrywide energy supplier and not as a city utility company." Notably, Utility Company C is the only one that does not include the name of the corresponding city in its company name.

Whether utility companies feel particularly obliged to their host cities also relates to whether citizens put specific trust in those companies. We clearly see this in the cases of A, B and D. The CEO of Utility Company D stated: "The utility company belongs to the local citizens and therefore they trust us more. Furthermore, the citizens are aware of our loyalty to the city." This could distinguish utility companies further from other external actors. The situation is different for Utility Company C. Having no direct customer relationship to the local citizens, it does not enjoy a special form of trust from them. 
In addition, our findings indicate that all four companies feel pressure to innovate. Innovation, however, is not only a pressure but also something they are interested in. This can be ascribed to the fact that the traditional business model of all the utility companies is changing very fast. The CEO of Utility Company B said: "I have the strong conviction that the next five to ten years will change our traditional business dramatically. We see a tremendous transformation." Even more pressing is the situation of Utility Company C because its business model was primarily based on the distribution of gas and its host city has ambitious environmental goals clashing with a business based on non-renewable resources. The situations of the utility companies in regard to innovation pressure are remarkably different from the local governments. The town clerk as a member of the local government of City I explained: “The city will certainly still exist in twenty years, it won't go bankrupt." We found that local governments saw no fundamental changes to their range of public services in the near future.

We were interested in whether higher innovation pressure for the utility companies results in the establishment of innovation units within these companies. This is only the case for Utility Companies C and D, both of which have designated innovation departments. In the case of Utility Company $\mathrm{C}$, this department even has an innovation fund available to support promising start-ups.

Finally, local governments and utility companies greatly differ in terms of business agility and error management culture (see also Soe \& Drechsler, 2018). As expected, from the local governments' points of view, government institutions are stable and reliable. The operations of local governments typically have a time horizon of decades and they have a strong emphasis on avoiding errors. The secretary general responsible for Utility Companies $\mathrm{B}$ and C explained: "Public administrations have an aversion to high risk and the ruling zeroerror-culture leads to a pressure for projects to be successful which prevents an innovation- 
friendly atmosphere.” Despite their long-time investment horizons, utility companies have started to become increasingly agile in adapting to the rapidly changing conditions.

\subsection{Relationships between Local Governments and Utility Companies}

Concerning smart city strategies, we found that only City III has already established such a strategy. In the other two cities, such a strategy either is under development or has been declared the goal of the current legislative period. The assignment mandate for Utility Companies A and D is a general one whereas for Utility Company B, the local government has issued performance contracts for several tasks such as operating a fiber optic network. In the case of Utility Company $\mathrm{C}$, the local government is represented in the supervisory board of the company. A specific innovation mandate has only been given to Utility Company D. Utility Company A has only a very general assignment to take innovative actions. However, the company wants a specific mandate as the head of the unit responsible for innovation told us: "There is no innovation mandate at the moment. We have wanted such a mandate for some time but without success. There must first be a common understanding of the initial positions and the goal to pursue. But this is absent today." Utility Companies B and C have no mandate specifically targeted at innovation. In general, we found that the more integrated into local governments the utility companies are, the more are they restricted by a dependence on political processes. The results in this perspective reflect the degree of organisational independence of the individual utility companies. This is expressed by the following statement of the CEO of Utility Company B: "As soon as we have to involve the parliament, it will delay our project by at least half a year and all that is discussed will be known to the public [and to competitors]."

In local governments, various players are responsible for the relation to the utility companies concerning IT-enabled product and service innovations for citizens. These actors 
play an important role as representatives of the principal. In the case of City I, this is the town clerk who is part of the city's chancellery. This person has a broad range of duties and responsibilities and consequently stated: "This sometimes makes me concerned that we do not have enough resources to deal with all the incoming innovative ideas." For Utility Companies B and C, the key player in the local government is the head of the office for economic development. For Utility Company D, the local government has established the position of a Chief Digital Officer, who sees as one of the position's main tasks ensuring that innovation remains citizen-orientated. This person highlighted the considerable efforts necessary to achieve this goal, telling us: "My role as Chief Digital Officer is to connect all the different departments [of the city government]."

An important aspect in a stewardship-like relation is the communication between principal and steward, a common understanding of the corresponding matter and the alignment of strategies and structures on both sides. Our findings show that for Utility Company A, the communication with the local government is difficult and, consequently, there is a lack of common understanding with the main actors using key terms on innovation and smart city quite differently. We also saw that the strategies and structures on both sides are not well aligned. This clearly contrasts with Utility Company D, which profits from efficient and regular communication, particularly between the Chief Digital Officer and the head of innovation of the utility company, leading to a solid alignment between strategies and structures on both sides. In Utility Company C, communication and a common understanding with the local government appear to be less relevant because it operates more independently. Consequently, the alignment in this case is of lower importance for innovation-related outcomes.

The different attributes of the relationship between utility companies and local governments correspond to different levels of agency and stewardship relationship 
characteristics. An assessment of these levels based on the different attributes is given in Figure 2.

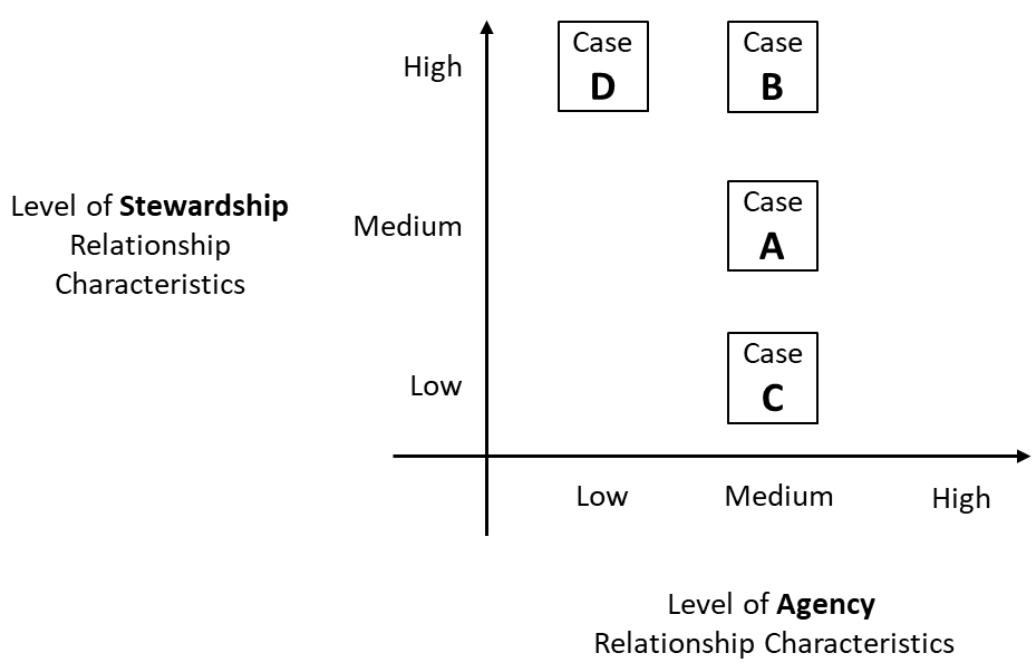

Figure 2. Level of agency- and stewardship relationship characteristics of the four cases analysed.

\subsection{Innovation-Related Outcomes}

Our theoretical model ascribes innovation-related outcomes, subdivided into the type of value creation and the level of innovativeness, to the attributes of the role of the utility companies and their relation to the local governments resulting in different levels of agency- and stewardship relationship characteristics. Our exploratory findings suggest that innovativeness is not only driven by an existing goal to innovate and planned and accomplished innovation projects, but is highly dependent on the role of the individual utility company and its relationship with the local government.

With regard to the type of innovation value creation, we found that all utility companies seek to innovate to achieve business value to secure and strengthen their own business. This is even true for Utility Company D that shows the lowest level of agency relationship characteristics. However, Utility Companies A, B and D also have the goal of striving for public value, which is a result of their increased values of stewardship 
relationship characteristics. This is most prominent and explicit in the case of Utility Company D. The goals specified in its assignment mandate include increasing the attractiveness of the city location and being part of the social environment of the city. These could both be attributed, according to Meynhardt (2009), to the political-social dimension of public value. For example, Case $\mathrm{D}$ aims at improving communication between districts, contributing to environmental protection, and utilizing sensors to make city life smart.

As for the dimension of utilitarian-instrumental public value, Utility Company D has the obligation to support the "2000-watt society" as part of a sustainable development of the city. The assignment mandate for Utility Company A states that the company should not only be committed to its customers but to every citizen of City I. Case A has developed smart city web and mobile applications, offering citizens public information and services. For example, an online reporting platform aims at facilitating the communication between citizens and public administration in terms of infrastructural defects. This resembles more of a public value view compared to business value. However, aiming at public value does not necessarily imply giving away services for free but the utility companies are glad to provide them at a cost-neutral level to allow others to create additional value for the local citizens. The CEO of Company B told us: "We contribute to the smart city by supplying the fiber optic network. We could even collect a multitude of data and provide it afterwards [to the citizens]." That Utility Company A does not only focus on business value is also noticed by the member of the executive government of City I, stating: "Utility Company A has even launched an energy-saving programme which potentially threatens their core business model." This reflects a public value orientation beyond self-interest.

Apart from general sustainability and ecological goals that are driven by their inherent business interests, we were unable to find clear indications that Utility Company $\mathrm{C}$ aims for public value in any of the four dimensions. In contrast, it focuses on privately owned 
businesses, thereby concentrating on achieving business value. This is a result of the lowest level of stewardship relationship characteristics found in the four cases. The head of corporate development of Utility Company C even stated that while the company is mostly owned by the city, their strategic objectives are influenced so marginally by the local government that ownership by private investors would not change their strategic goals at all. Summarising, we see that stewardship relationship characteristics promote IT-enabled collaborative innovation geared towards both public value and business value creation, whereas agency relationship characteristics lead to innovations mostly geared towards business value. Not only the relationship characteristics, but also the types of collaborative innovations implemented give some indications of the type of value creation.

Regarding the level of innovativeness, the role and relationship between utility company and local government is most beneficial in the case of Utility Company D, resulting in a high degree of innovativeness. This finding is supported by the following quote of the Chief Digital Officer of City III: "The chairs [of the innovation board] will be the head of innovation of the utility company and myself so that we can come out of a 'silo-mindset' and produce strong collaboration, and that we can also distribute what we learn to other departments." The high innovativeness of Utility Company $\mathrm{C}$ is largely owing to its strong innovation department. The head of corporate development of Utility Company C stated: "Our [innovation] team can quickly react to [changing] customer needs." The low innovativeness of Utility Company A can be attributed to its difficult relationship with the local government. This conclusion is backed by a statement given by the CEO of Utility Company A: "We asked the local government to give us an innovation mandate but the councillors did not want to [...]. The way they would like us to act would cause us problems." The medium level of innovativeness of Utility Company B is a result of strategies and structures, which are established but not well rehearsed. To sum up, regarding the level of 
innovativeness in collaborative innovation, both stewardship and agency relationship characteristics tend to increase the overall innovativeness in IT-enabled innovation. Although all cases analysed have implemented collaborative innovations already, they differ with regard to the level of innovativeness due to variations in role and relationship characteristics.

A structured summary of our results with regard to the role of the individual utility companies, their relation to the local governments, the resulting level of agency- and stewardship characteristics and the subsequent innovation-related outcomes is presented in Table 3. The assignment of the categories low, medium and high to the attributes of the perspectives is based on the number and significance of the statements of the interviewees.

They represent a relative positioning of the cases examined.

\begin{tabular}{|c|c|c|c|c|c|}
\hline Perspective & Attributes & Case A & Case B & Case C & Case D \\
\hline \multirow{7}{*}{$\begin{array}{l}\text { Role of } \\
\text { utility } \\
\text { company }\end{array}$} & $\begin{array}{l}\text { Identification } \\
\text { with city }\end{array}$ & High & High & Low & High \\
\hline & Trust by citizens & High & High & Low & High \\
\hline & $\begin{array}{l}\text { Pressure to } \\
\text { innovate }\end{array}$ & High & High & High & High \\
\hline & $\begin{array}{l}\text { Innovation } \\
\text { department }\end{array}$ & None & None & Yes & Yes \\
\hline & $\begin{array}{l}\text { Key actors } \\
\text { for innovation }\end{array}$ & $\begin{array}{l}\text { Head of } \\
\text { marketing } \\
\text { and sales }\end{array}$ & $\begin{array}{l}\text { Head of } \\
\text { telecom unit }\end{array}$ & $\begin{array}{l}\text { Head of } \\
\text { corporate } \\
\text { development }\end{array}$ & $\begin{array}{l}\text { Head of } \\
\text { innovation }\end{array}$ \\
\hline & Business agility & Medium & Medium & High & Medium \\
\hline & $\begin{array}{l}\text { Error } \\
\text { management } \\
\text { culture }\end{array}$ & Medium & Medium & High & Medium \\
\hline
\end{tabular}




\begin{tabular}{|c|c|c|c|c|c|}
\hline \multirow[t]{10}{*}{$\begin{array}{l}\text { Relationship } \\
\text { with local } \\
\text { government }\end{array}$} & $\begin{array}{l}\text { Smart City } \\
\text { strategy of local } \\
\text { government }\end{array}$ & $\begin{array}{l}\text { Intention to } \\
\text { develop }\end{array}$ & $\begin{array}{l}\text { Under } \\
\text { development }\end{array}$ & $\begin{array}{l}\text { Under } \\
\text { development }\end{array}$ & Established \\
\hline & $\begin{array}{l}\text { Type of } \\
\text { assignment } \\
\text { mandate }\end{array}$ & $\begin{array}{l}\text { General } \\
\text { strategy }\end{array}$ & $\begin{array}{l}\text { Performance } \\
\text { contract }\end{array}$ & $\begin{array}{l}\text { Participation } \\
\text { in } \\
\text { supervisory } \\
\text { board }\end{array}$ & $\begin{array}{l}\text { General } \\
\text { strategy }\end{array}$ \\
\hline & $\begin{array}{l}\text { Innovation } \\
\text { mandate }\end{array}$ & General & None & None & Specific \\
\hline & $\begin{array}{l}\text { Dependence of } \\
\text { utility company } \\
\text { on political } \\
\text { processes }\end{array}$ & Medium & High & Low & High \\
\hline & $\begin{array}{l}\text { Key local } \\
\text { government } \\
\text { actor for relation } \\
\text { with utility } \\
\text { company }\end{array}$ & Town clerk & $\begin{array}{l}\text { Head of } \\
\text { economic } \\
\text { development }\end{array}$ & $\begin{array}{l}\text { Head of } \\
\text { economic } \\
\text { development }\end{array}$ & $\begin{array}{l}\text { Chief } \\
\text { Digital } \\
\text { Officer }\end{array}$ \\
\hline & $\begin{array}{l}\text { Communication } \\
\text { between local } \\
\text { government and } \\
\text { utility company }\end{array}$ & Difficult & $\begin{array}{l}\text { Established } \\
\text { but not well- } \\
\text { rehearsed }\end{array}$ & $\begin{array}{l}\text { Low } \\
\text { relevance }\end{array}$ & $\begin{array}{l}\text { Well- } \\
\text { rehearsed }\end{array}$ \\
\hline & $\begin{array}{l}\text { Common } \\
\text { understanding of } \\
\text { innovation }\end{array}$ & Low & Medium & $\begin{array}{l}\text { Low } \\
\text { relevance }\end{array}$ & High \\
\hline & $\begin{array}{l}\text { Alignment of } \\
\text { strategies and } \\
\text { structures }\end{array}$ & Low & Medium & $\begin{array}{l}\text { Low } \\
\text { relevance }\end{array}$ & High \\
\hline & $\begin{array}{l}\text { Level of agency } \\
\text { relationship } \\
\text { characteristics }\end{array}$ & Medium & Medium & Medium & Low \\
\hline & $\begin{array}{l}\text { Level of } \\
\text { stewardship } \\
\text { relationship } \\
\text { characteristics }\end{array}$ & Medium & High & Low & High \\
\hline
\end{tabular}




\begin{tabular}{|l|l|l|l|l|l|}
\hline $\begin{array}{l}\text { Innovation- } \\
\text { related } \\
\text { outcome }\end{array}$ & $\begin{array}{l}\text { Type of value } \\
\text { creation }\end{array}$ & $\begin{array}{l}\text { Business } \\
\text { and Public } \\
\text { value }\end{array}$ & $\begin{array}{l}\text { Business } \\
\text { and Public } \\
\text { value }\end{array}$ & $\begin{array}{l}\text { Business } \\
\text { value }\end{array}$ & $\begin{array}{l}\text { Business } \\
\text { and Public } \\
\text { value }\end{array}$ \\
\cline { 2 - 6 } & $\begin{array}{l}\text { Level of } \\
\text { innovativeness }\end{array}$ & Low & Medium & High & High \\
\hline
\end{tabular}

Table 3. Summary of interview findings.

\section{Propositions and Implications}

\subsection{Propositions}

Our research aimed at identifying whether collaborative innovation between local governments and utility companies in smart city initiatives can fulfil the intended goal of creating public value and how such relationships need to be designed for this purpose. In this section, we summarise our key findings and derive three propositions.

First, our results illustrate that, although local governments strive to advance ITenabled innovation, they indeed face various constraints in technological expertise and financial resources, which seem to be particularly prevalent in smart city projects owing to the complexity of the technological design and the number of parties involved. However, upon collaborating with utility companies, local governments benefit from the companies' innovation assets such as pressure to innovate, higher levels of agility, and an established failure management culture. So, based on our exploratory findings we assert that collaborative innovation appears to be a viable approach to increase innovativeness in smart city initiatives. This result is consistent across public and semi-public utility companies and relatively independent of how closely the utility company is organisationally integrated into the local government. So, regardless of whether a stewardship-like relationship or an agencylike relationship between a local government and a utility company is used, the innovativeness of the local government will increase through the collaborative innovation 
with the utility company. Importantly, this does not say anything about the type of value (public or business) that is created by the resulting innovations yet. Accordingly, we conclude:

Proposition 1: Regarding the level of innovativeness in collaborative innovation, both stewardship and agency relationships between a local government and a utility company will increase the overall innovativeness in IT-enabled innovation.

Second, our findings suggest that the type of collaborative innovation relationship between the local government and the utility company has an impact on the type of value that is created through the collaborative innovation. More specifically, a stewardship relationship between local governments and utility companies tends to lead to innovations geared towards both public value and business value, whereas principal-agent relationships tend to purely foster business value creation. While all utility companies in our sample primarily innovate based on expected financial returns, the utility companies characterised as stewards do not exclusively aim for business value but also feel more responsible for pursuing the overall goal of generating public value. This is emphasised by expressions of internalised goals geared towards public value creation by interview partners from utility companies whose relationship with the local government tends to be based on stewardship, particularly in the political-social (e.g. citizen involvement, compromise) and utilitarian-instrumental (e.g. openness, sustainability) public value dimensions (Meynhardt, 2009). Based on this finding we conclude:

Proposition 2: Regarding the type of value creation in collaborative innovation, a stewardship relationship between a local government and a utility company promotes ITenabled collaborative innovation geared towards both public value and business value creation, whereas agency relationships will lead to innovations mostly geared towards business value. 
Third, our findings indicate that if a collaboration between a local government and a utility company can neither be characterised as a stewardship relationship nor an agency relationship with clearly defined mandate and control mechanisms, or if the collaboration is simply not close enough, there will be a lack of common understanding of the aims of the collaborative innovation. This might be even more explicit in IT-enabled smart city initiatives since these often provide some leeway for the process as well as the final outcome of the project owing to their complexity. However, as a result of the lacking common understanding, the cities' innovativeness will not profit from the collaboration. According to agency theory, an explicit mandate and control mechanisms are preconditions for a common understanding. If set up appropriately and if the context is considered carefully (Cordella \& Cordella, 2017), they can help develop an agency relationship into a stewardship relationship over time (Van Slyke, 2006). Beyond these two pure forms, hybrids of agency and stewardship relationships can also lead to successful partnerships (Huang, Baptista, \& Newell, 2015; Sundaramurthy \& Lewis, 2003). Importantly, the lack of an increased innovativeness of a local government in such cases also implies that the potential for both public value and business value creation through IT-enabled innovations will not be levered. Therefore, we conclude:

Proposition 3: If there is neither a stewardship nor an agency relationship (nor a hybrid of the two) between a local government and a utility company, a lack of common understanding of the collaborative innovation will hamper the improvement of the cities' innovativeness, which in turn means that certain potential for public value creation through IT-enabled innovations will not be exploited.

\subsection{Implications for Research}

Foremost, this study has implications for research on public value creation when multiple 
stakeholders are involved (Bryson et al., 2017; Hartley et al., 2017; Page et al., 2015). We contribute by examining how local governments collaborate with utility companies to introduce complex, IT-enabled initiatives and thereby produce "value-creating public innovation" (Crosby et al., 2017, p. 659; Geuijen et al., 2017). The findings of the comparative case study analysis give empirical evidence that creating public value from collaborative innovation is a complex process (see also Cordella \& Bonina, 2012). In particular, the collaboration between local governments and utility companies that might be characterised by conflicts of interest in terms of the objectives of IT-enabled initiatives involves a priori challenges that have to be overcome during the innovation process to pursue public value. In order to understand how negative outcomes of IT collaboration to the detriment of public value can be reduced (Cordella \& Willcocks, 2010), we have empirically analysed which conditions are best suited to create public value in such collaborative innovation by combining the insights from public managers, local politicians, and collaboration partners (Hartley et al., 2017). We thus not only analyse the performance of collaborative innovation, but also look more closely which type of relationships between innovation partners results in which type of outcome. This analysis of how public value can be created contributes to previous literature in reasoning by established theories and providing empirical examples why public value creation is characterised by high complexity. Applying both agency and stewardship theory makes it possible to get a more refined picture on the potential of generating public value with collaborative innovation, in addition to seeking for managerial outcomes and business goals (Cordella \& Bonina, 2012). We thus contribute to public value literature by investigating value creation in the context of collaborative innovation and measuring the value created for both governments and nongovernmental partners (Klievink et al., 2016; Twizeyimana \& Andersson, 2019). More specifically, we describe how collaborations that are entered due to efficacy and innovation 
reasons can lead to seeking public value, a topic of high relevance when considering the importance of collaboration for public sector organisations.

Our study has implications for research on collaborative innovation by investigating how local governments work together with utility companies to enhance innovativeness (Page et al., 2015). More specifically, we examine which role utility companies play in smart city innovation projects and how their relationship is characterised. We show that the type of relationship influences the local government's innovativeness, and thus take a first step towards assessing the outcomes of collaborative innovation (Torfing, 2019).

While organisational innovation efforts have been studied extensively in business research (Devece, Palacios-Marqués, Galindo-Martín, \& Llopis-Albert, 2017; Roberts, Campbell, \& Vijayasarathy, 2016) and public administration research (Grimmelikhuijsen \& Feeney, 2017; Hansen, 2011), this study combines the rationales of both the semi-public and public sectors investigating the inter-organisational collaborations in IT-enabled innovations. While researchers have already adopted institutional theory to study institutional forces driving innovation adoption (Bunduchi, Smart, Charles, McKee, \& Azuara-Blanco, 2015; ElHaddadeh, Weerakkody, \& Al-Shafi, 2013), our approach to collaborative innovation linking public management literature with other literature streams from public sector innovation research and information systems, proposes an actor-centric perspective to better understand the emergence of innovations focused on creating public value. To explain these relationships, we develop a model contrasting agency theory with stewardship theory. In line with Hirsch et al. (1987) and Davis et al. (1997), we suggest that the limits of agency theory have to be acknowledged when analysing relationships between government institutions and (semi-)private business actors. Stewardship theory can lend a helping hand to agency theory due to its focus on goal congruence. We therefore also contribute to theoretical discussions 
concerning relationships between two actors collaborating in innovation projects that go beyond the smart city context investigated here.

\subsection{Implications for Practice}

In addition to the implications for research, this study offers recommendations for practitioners in local public administration, public and semi-public utility companies, and possibly also for other types of SOEs or other forms of collaborative innovation between public and private sector partners in the context of IT-enabled innovations and smart city programmes.

First and foremost, when the goal is to create public value through collaborative innovation, which usually is the goal in smart city initiatives, it is important to understand that the design of the collaboration matters. More specifically, public managers should strive to establish a stewardship-type relationship with their innovation partners. To that end, public managers are advised to generally create a very close relationship with the innovation partner, e.g. a utility company, that is characterised by mutual trust and empowerment instead of monitoring and control. A close organisational integration of the innovation partner, such as a utility company, can facilitate this, as can regular communication and a high identification with the city by the innovation partner. It should, where possible, be avoided to contract out innovation, giving mandates to innovation partners and expecting them to independently create and deliver innovations in return for remuneration. Instead, collaboration should be understood literally as working together to create public value. Particular attention should also be paid to creating a common vision of the goals of the collaboration, focusing on creating public value. In this, public managers should emphasise and explain transparently that the collaborative innovation is about creating public value (or creating value in certain public value dimensions; (Meynhardt, 2009)) and serving the citizens of the city, as 
"stewardship begins with the willingness to be accountable for some larger body than ourselves" (Block, 2013, p. 16). Arguably, this is easier to achieve with public and semipublic organisations, such as the utility companies studied here, than with private sector organisations.

Second, our findings indicate that many utility companies, at least in Switzerland, are generally willing to contribute their innovation resources such as technical knowhow and process experience to a trustful relationship with local governments. However, an optimal collaboration relationship requires close ties between relevant exponents from the utility company with a department in the local government that has an affinity to innovation processes and supports the utility company with information and involvement on the political level. Therefore, we suggest positioning the management of innovation programmes, such as smart city or digitalisation strategies for governmental units, close to influential political actors such as a mayor's department or an office for economic development, that will then coordinate the collaboration with the innovation partner(s) and ensure that the focus remains on creating public value. As such, in an ideal setting, the local government acts as a partner enabling the utility company to innovate successfully for the citizens in close collaboration. Thus, local governments, although typically characterised by lower innovativeness due to bureaucracy and legal constraints, can yet foster innovation and thereby increase public value driven by utility companies as trusted partners.

Third, utility companies are usually attractive employers for innovative, technically experienced employees motivated to use their skills for their own city. Moreover, due to their market-orientation, utility companies strive to signal their innovativeness and competitiveness publicly. At the same time, public and semi-public utility companies often have very close ties to and existing personal networks within local governments. Therefore, it is advised to specifically involve public and semi-public utility companies in collaborative 
innovation to make use of their additional innovation resources. This may also hold for other public sector innovation initiatives and contests such as hackathons (Johnson \& Robinson, 2014) and it may even be worth considering to let the utility company take on a leadership role in such processes. For the Anglo-Saxon context, it is advised to work towards a more joined-up mode of collaboration with utility companies and other collaboration partners that have previously been privatised, in an effort to return to a more horizontally coordinated setup that will allow for stewardship-type relationships in collaborative innovation (see also Cordella \& Bonina, 2012).

\section{Conclusion, Limitations, and Future Work}

While it is known that IT-enabled innovations have large potential to improve public value creation (Cordella \& Bonina, 2012; Pang et al., 2014), particularly in smart city initiatives (Gil-Garcia et al., 2016), we also know that such projects frequently fail and their outcomes are not always for the better or in very public interest (Bannister \& Connolly, 2014). To improve their innovativeness regarding IT-enabled innovations in smart city programmes, many local governments in continental Europe have started using collaborative innovation approaches with public and semi-public utility companies. However, thus far it was unclear how such collaborations may lead to public value creation and how exactly they need to be designed. Thus, we have to improve our understanding of whether and how utility companies - or other innovation partners - can contribute to public value creation by actively engaging in local governments' innovation projects and thereby make cities smarter (Gil-Garcia et al., 2016). In this study, we draw on both agency and stewardship theory to explore the cases of four public utility companies in Switzerland and their relations with three different cities in smart city initiatives. 
Our key findings are that the collaborative innovation approaches and the resulting innovation-related outcomes differ substantially in their form and scope. To summarise, both types of relationship (agency and stewardship) between a local government and a utility company, if designed adequately, have been found to contribute to higher innovativeness of the local government or city in general, because the utility companies under study indeed tend to have specific innovation assets that local governments lack and that are essential in such more complex smart city initiatives. In addition, utility companies have certain advantages over completely private companies, such as closer ties and mutual trust with the local governments, which help promoting innovation in the public sphere.

However, the resulting innovation-related outcomes differ substantially in terms of whether business value or public value are created, depending on whether an agency or stewardship model of collaboration is used. Utility companies acting as stewards tend to feel more committed to help create public value, which does not mean that they would stop entirely to pursue their own business interests. On the other hand, utility companies acting as agents remain focused rather strongly on creating business value for themselves in collaborative innovation. Therefore, local governments need to choose adequate governance mechanisms according to the predisposition of the characteristics and their relationship with utility companies in order to exploit the public value creation potential of their partners in innovation projects (see also Bryson et al., 2014). Of course, although innovation partners such as utility companies may place their focus on business value, it should also be noted that certain innovations resulting from an agency-type collaborative innovation may - even if not intended - as a by-product of business value also create a certain public value. This could be the case, for instance, if an innovation that increases the cost-efficiency of the innovation partner also happens to save environmental resources and thereby create public value in the dimension of sustainability. 
Our study has several limitations, some of which provide promising areas for future research. In this study, we have focused on investigating the role of public utility companies as one specific case of SOEs and their relations with local governments in smart city programmes in Switzerland. Although we assume that these relationships are somewhat representative for other continental European countries as well, we acknowledge that results might differ across countries. This may be the case especially for countries featuring different political systems or higher degrees of privatisation of public infrastructure, such as the Anglo-Saxon ones. Thus, as the generalisability of our findings is unclear, we recommend conducting more research on the topic in other countries and in contexts other than smart city programmes to compare the findings.

Moreover, in other contexts, other types of SOEs such as less technology-oriented ones, or even citizens (see e.g. Meijer, 2015) may also be acting as innovation partners of governments at all levels. In this light, it might be worthwhile to search for possible differences and similarities to the IT-enabled collaborative innovation initiatives between local governments and utility companies studied here. While we have in this study focused on public value creation and the citizen centricity-dimension of the smartness concept (GilGarcia et al., 2016), future research could also adopt a different perspective, for instance by drawing on the citizen engagement or sustainability dimension of smartness.

More investigation is also required to gain insight into how the collaboration between public administrations and innovation partners such as utility companies affects public sector innovation in the long-term. While we have adopted a cross-sectional view that allowed capturing innovation activities around public-value focused product and service innovation, we were not able to monitor innovation success in the long run.

In addition, owing to the qualitative nature of our study, it was not possible to empirically validate the success of such innovation projects and associate them with specific 
key performance indicators. This was also partly due to the "complexity and ambiguity of public value" (Hartley et al., 2017, p. 671) which makes objective measurement difficult. For future research, we suggest using our exploratory insights as a first step to develop a quantitative survey in order to record the views of a larger number of local governments (or other levels of government) and to assess the effect of different forms of collaboration at a larger and more international scale. In this sense, also the role of the public utility company might be different. While we analysed cases in which the public utility company served as the main innovation agent for the local government, there might also be large innovation networks, in which the public utility company could have a much smaller share, and which should be analysed as well.

Lastly, by focusing on IT-enabled innovations in smart city initiatives, we have confined ourselves to a particular type of innovation in the local public sector. However, circumstances and innovation-related outcomes might be different for strategic or process innovation (Hartley, 2005) which could affect public administrations as well as innovation partners. We therefore recommend that future research expand the scope and focus towards other types of innovation.

\section{References}

Anthopoulos, L., Janssen, M., \& Weerakkody, V. (2016). A Unified Smart City Model (USCM) for Smart City Conceptualization and Benchmarking: International Journal of Electronic Government Research, 12(2), 77-93. https://doi.org/10.4018/IJEGR.2016040105

Argyris, C. (1972). Integrating the Individual and the Organization. New Brunswick (U.S.A) and London (U.K): Transaction Publishers.

Arthurs, J. D., \& Busenitz, L. W. (2003). The Boundaries and Limitations of Agency Theory and Stewardship Theory in the Venture Capitalist/Entrepreneur Relationship. 
Entrepreneurship Theory and Practice, 28(2), 145-162.

https://doi.org/10.1046/j.1540-6520.2003.00036.x

Bannister, F., \& Connolly, R. (2014). ICT, public values and transformative government: A framework and programme for research. Government Information Quarterly, 31(1), 119-128. https://doi.org/10.1016/j.giq.2013.06.002

Barringer, B. R., \& Harrison, J. S. (2000). Walking a tightrope: Creating value through interorganizational relationships. Journal of Management, 26(3), 367-403. https://doi.org/10.1016/S0149-2063(00)00046-5

Benington, J. (2009). Creating the Public In Order To Create Public Value? International Journal of Public Administration, 32(3-4), 232-249.

https://doi.org/10.1080/01900690902749578

Benington, J., \& Moore, M. H. (2010). Public Value: Theory and Practice. London: Palgrave Macmillan.

Block, P. (2013). Stewardship: Choosing service over self-interest (Second edition, revised and expanded). San Francisco: Berrett-Koehler Publishers.

Bommert, B. (2010). Collaborative innovation in the public sector. International Public Management Review, 11(1), 15-33.

Borins, S. (2001). Encouraging innovation in the public sector. Journal of Intellectual Capital, 2(3), 310-319. https://doi.org/10.1108/14691930110400128

Bryson, J., Crosby, B. C., \& Bloomberg, L. (2014). Public Value Governance: Moving Beyond Traditional Public Administration and the New Public Management. Public Administration Review, 74(4), 445-456. https://doi.org/10.1111/puar.12238

Bryson, J., Sancino, A., Benington, J., \& Sørensen, E. (2017). Towards a multi-actor theory of public value co-creation. Public Management Review, 19(5), 640-654. https://doi.org/10.1080/14719037.2016.1192164 
Bunduchi, R., Smart, A., Charles, K., McKee, L., \& Azuara-Blanco, A. (2015). When innovation fails: An institutional perspective of the (non) adoption of boundary spanning IT innovation. Information \& Management, 52(5), 563-576. https://doi.org/10.1016/j.im.2015.04.001

Corbetta, G., \& Salvato, C. (2004). Self-serving or self-actualizing? Models of man and agency costs in different types of family firms: A commentary on "comparing the agency costs of family and non-family firms: Conceptual issues and exploratory evidence." Entrepreneurship Theory and Practice, 28(4), 355-362. https://doi.org/10.1111/j.1540-6520.2004.00050.x

Cordella, A. (2007). E-government: Towards the e-bureaucratic form? Journal of Information Technology, 22(3), 265-274. https://doi.org/10.1057/palgrave.jit.2000105

Cordella, A., \& Bonina, C. M. (2012). A public value perspective for ICT enabled public sector reforms: A theoretical reflection. Government Information Quarterly, 29(4), 512-520. https://doi.org/10.1016/j.giq.2012.03.004

Cordella, A., \& Cordella, T. (2017). Motivations, monitoring technologies, and pay for performance. Journal of Economic Behavior \& Organization, 133, 236-255. https://doi.org/10.1016/j.jebo.2016.10.016

Cordella, A., \& Paletti, A. (2018). ICTs and value creation in public sector: Manufacturing logic vs service logic. Information Polity, 23(2), 125-141. https://doi.org/10.3233/IP170061

Cordella, A., \& Willcocks, L. (2010). Outsourcing, bureaucracy and public value: Reappraising the notion of the "contract state." Government Information Quarterly, 27(1), 82-88. https://doi.org/10.1016/j.giq.2009.08.004

Creswell, J. W., \& Creswell, J. D. (2018). Research design: Qualitative, quantitative, and mixed methods approaches. Los Angeles: Sage. 
Crosby, B. C., 't Hart, P., \& Torfing, J. (2017). Public value creation through collaborative innovation. Public Management Review, 19(5), 655-669. https://doi.org/10.1080/14719037.2016.1192165

Daglio, M., Gerson, D., \& Kitchen, H. (2015). Building Organisational Capacity for Public Sector Innovation. Background Paper Prepared for the OECD Conference "Innovating the Public Sector: From Ideas to Impact”, Paris, 12-13 November 2014, 1-35. Paris.

Davis, J. H., Schoorman, F. D., \& Donaldson, L. (1997). Toward a stewardship theory of management. Academy of Management Review, 22(1), 20-47. https://doi.org/10.5465/amr.1997.9707180258

De Vries, H., Bekkers, V., \& Tummers, L. (2016). Innovation in the public sector: A systematic review and future research agenda. Public Administration, 94(1), 146-166. https://doi.org/10.1111/padm.12209

Devece, C., Palacios-Marqués, D., Galindo-Martín, M.-Á., \& Llopis-Albert, C. (2017). Information Systems Strategy and its Relationship With Innovation Differentiation and Organizational Performance. Information Systems Management, 34(3), 250-264. https://doi.org/10.1080/10580530.2017.1330002

Donaldson, L., \& Davis, J. H. (1991). Stewardship theory or agency theory: CEO governance and shareholder returns. Australian Journal of Management, 16(1), 49-64. https://doi.org/10.1177/031289629101600103

Eddleston, K. A., \& Kellermanns, F. W. (2007). Destructive and productive family relationships: A stewardship theory perspective. Journal of Business Venturing, 22(4), 545-565. https://doi.org/10.1016/j.jbusvent.2006.06.004

Eisenhardt, K. M. (1989). Agency Theory: An Assessment and Review. The Academy of Management Review, 14(1), 57-74. https://doi.org/10.2307/258191 
Eisenhardt, K. M. (1991). Better stories and better constructs: The case for rigor and comparative logic. Academy of Management Review, 16(3), 620-627. https://doi.org/10.5465/amr.1991.4279496

Eisenhardt, K. M., \& Graebner, M. E. (2007). Theory building from cases: Opportunities and challenges. Academy of Management Journal, 50(1), 25-32. https://doi.org/10.5465/amj.2007.24160888

El-Haddadeh, R., Weerakkody, V., \& Al-Shafi, S. (2013). The complexities of electronic services implementation and institutionalisation in the public sector. Information \& Management, 50(4), 135-143. https://doi.org/10.1016/j.im.2013.02.005

Feiock, R. C., Lee, I. W., Park, H. J., \& Lee, K.-H. (2010). Collaboration networks among local elected officials: Information, commitment, and risk aversion. Urban Affairs Review, 46(2), 241-262. https://doi.org/10.1177/1078087409360509

Frey, B. S., \& Jegen, R. (2001). Motivation Crowding Theory. Journal of Economic Surveys, 15(5), 589-611. https://doi.org/10.1111/1467-6419.00150

Gascó, M. (2017). Living labs: Implementing open innovation in the public sector. Government Information Quarterly, 34(1), 90-98. https://doi.org/10.1016/j.giq.2016.09.003

Geuijen, K., Moore, M., Cederquist, A., Ronning, R., \& van Twist, M. (2017). Creating public value in global wicked problems. Public Management Review, 19(5), 621-639. https://doi.org/10.1080/14719037.2016.1192163

Gil-Garcia, J. R., Helbig, N., \& Ojo, A. (2014). Being smart: Emerging technologies and innovation in the public sector. Government Information Quarterly, 31(Supplement 1), I1-I8. https://doi.org/10.1016/j.giq.2014.09.001 
Gil-Garcia, J. R., Zhang, J., \& Puron-Cid, G. (2016). Conceptualizing smartness in government: An integrative and multi-dimensional view. Government Information Quarterly, 33(3), 524-534. https://doi.org/10.1016/j.giq.2016.03.002

Grimmelikhuijsen, S. G., \& Feeney, M. K. (2017). Developing and testing an integrative framework for open government adoption in local governments. Public Administration Review, 77(4), 579-590. https://doi.org/10.1111/puar.12689

Hansen, M. B. (2011). Antecedents of organizational innovation: The diffusion of new public management into Danish local government. Public Administration, 89(2), 285-306. https://doi.org/10.1111/j.1467-9299.2010.01855.x

Hartley, J. (2005). Innovation in Governance and Public Services: Past and Present. Public Money \& Management, 25(1), 27-34. https://doi.org/10.1111/j.14679302.2005.00447.x

Hartley, J., Alford, J., Knies, E., \& Douglas, S. (2017). Towards an empirical research agenda for public value theory. Public Management Review, 19(5), 670-685. https://doi.org/10.1080/14719037.2016.1192166

Hartley, J., Sørensen, E., \& Torfing, J. (2013). Collaborative innovation: A viable alternative to market competition and organizational entrepreneurship. Public Administration Review, 73(6), 821-830. https://doi.org/10.1111/puar.12136

Hirsch, P., Michaels, S., \& Friedman, R. (1987). Dirty hands" versus “clean models. Theory and Society, 16(3), 317-336. https://doi.org/10.1007/BF00139485

Huang, J., Baptista, J., \& Newell, S. (2015). Communicational ambidexterity as a new capability to manage social media communication within organizations. The Journal of Strategic Information Systems, 24(2), 49-64. https://doi.org/10.1016/j.jsis.2015.03.002 
Jensen, M. C., \& Meckling, W. H. (1976). Theory of the firm: Managerial behavior, agency costs and ownership structure. Journal of Financial Economics, 3(4), 305-360. https://doi.org/10.1016/0304-405X(76)90026-X

Johnson, P., \& Robinson, P. (2014). Civic hackathons: Innovation, procurement, or civic engagement? Review of Policy Research, 31(4), 349-357. https://doi.org/10.1111/ropr.12074

Jørgensen, T. B., \& Bozeman, B. (2007). Public values: An inventory. Administration \& Society, 39(3), 354-381. https://doi.org/10.1177/0095399707300703

Kankanhalli, A., Charalabidis, Y., \& Mellouli, S. (2019). IoT and AI for smart government: A research agenda. Government Information Quarterly, 36(2), 304-309. https://doi.org/10.1016/j.giq.2019.02.003

Kankanhalli, A., Zuiderwijk, A., \& Tayi, G. K. (2017). Open innovation in the public sector: A research agenda. Government Information Quarterly, 34(1), 84-89. https://doi.org/10.1016/j.giq.2016.12.002

King, G., Keohane, R. O., \& Verba, S. (1994). Designing Social Inquiry: Scientific Inference in Qualitative Research. Princeton, New Jersey: Princeton University Press.

Klievink, B., Bharosa, N., \& Tan, Y.-H. (2016). The collaborative realization of public values and business goals: Governance and infrastructure of public-private information platforms. Government Information Quarterly, 33(1), 67-79. https://doi.org/10.1016/j.giq.2015.12.002

Koppenjan, J. F. M., \& Klijn, E.-H. (2004). Managing Uncertainties in Networks: A Network Approach to Problem Solving and Decision Making. London: Routledge.

Kuckartz, U. (2014). Qualitative Text Analysis: A Guide to Methods, Practice and Using Software. Los Angeles: Sage. 
Lee, J., \& Lee, H. (2014). Developing and validating a citizen-centric typology for smart city services. Government Information Quarterly, 31, S93-S105.

https://doi.org/10.1016/j.giq.2014.01.010

Mayring, P. (2014). Qualitative content analysis: Theoretical foundation, basic procedures and software solution. Monograph, Klagenfurt.

Meijer, A. (2015). E-governance innovation: Barriers and strategies. Government Information Quarterly, 32(2), 198-206. https://doi.org/10.1016/j.giq.2015.01.001

Meijer, A., \& Bolívar, M. P. R. (2016). Governing the smart city: A review of the literature on smart urban governance. International Review of Administrative Sciences, 82(2), 392-408. https://doi.org/10.1177/0020852314564308

Meynhardt, T. (2009). Public value inside: What is public value creation? International Journal of Public Administration, 32(3-4), 192-219.

https://doi.org/10.1080/01900690902732632

Moore, M. H. (1995). Creating public value: Strategic management in government. Harvard university press.

Mulgan, G., \& Albury, D. (2003). Innovation in the public sector. Strategy Unit, Cabinet Office, UK.

Naphade, M., Banavar, G., Harrison, C., Paraszczak, J., \& Morris, R. (2011). Smarter Cities and Their Innovation Challenges. Computer, 44(6), 32-39. https://doi.org/10.1109/MC.2011.187

OECD. (2017). The Size and Sectoral Distribution of State-Owned Enterprises. Paris: OECD Publishing.

Ospina, S. M., Esteve, M., \& Lee, S. (2018). Assessing Qualitative Studies in Public Administration Research. Public Administration Review, 78(4), 593-605. https://doi.org/10.1111/puar.12837 
Page, S. B., Stone, M. M., Bryson, J. M., \& Crosby, B. C. (2015). Public value creation by cross-sector collaborations: A framework and challenges of assessment. Public Administration, 93(3), 715-732. https://doi.org/10.1111/padm.12161

Pandey, S. K., \& Stazyk, E. C. (2008). Antecedents and correlates of public service motivation. In J. L. Perry \& A. Hondeghem (Eds.), Motivation in public management: The call of public service (pp. 101-117). Oxford: Oxford University Press.

Pang, M.-S., Lee, G., \& DeLone, W. H. (2014). IT resources, organizational capabilities, and value creation in public-sector organizations: A public-value management perspective. Journal of Information Technology, 29(3), 187-205. https://doi.org/10.1057/jit.2014.2

Ritz, A., Brewer, G. A., \& Neumann, O. (2016). Public service motivation: A systematic literature review and outlook. Public Administration Review, 76(3), 414-426. https://doi.org/10.1111/puar.12505

Roberts, N., Campbell, D. E., \& Vijayasarathy, L. R. (2016). Using information systems to sense opportunities for innovation: Integrating postadoptive use behaviors with the dynamic managerial capability perspective. Journal of Management Information Systems, 33(1), 45-69. https://doi.org/10.1080/07421222.2016.1172452

Ross, S. A. (1973). The economic theory of agency: The principal's problem. The American Economic Review, 63(2), 134-139.

Scupola, A., \& Zanfei, A. (2016). Governance and innovation in public sector services: The case of the digital library. Government Information Quarterly, 33(2), 237-249. https://doi.org/10.1016/j.giq.2016.04.005

Shumate, P. W. (2008). Fiber-to-the-home: 1977-2007. Journal of Lightwave Technology, 26(9), 1093-1103. https://doi.org/10.1109/JLT.2008.923601 
Soe, R.-M., \& Drechsler, W. (2018). Agile local governments: Experimentation before implementation. Government Information Quarterly, 35(2), 323-335. https://doi.org/10.1016/j.giq.2017.11.010

Sørensen, E., \& Torfing, J. (2011). Enhancing collaborative innovation in the public sector. Administration \& Society, 43(8), 842-868. https://doi.org/10.1177/0095399711418768

Sørensen, E., \& Torfing, J. (2012). Introduction: Collaborative innovation in the public sector. The Innovation Journal, 17(1), 1.

Sørensen, E., \& Torfing, J. (2017). Metagoverning collaborative innovation in governance networks. The American Review of Public Administration, 47(7), 826-839. https://doi.org/10.1177/0275074016643181

Sundaramurthy, C., \& Lewis, M. (2003). Control and collaboration: Paradoxes of governance. Academy of Management Review, 28(3), 397-415. https://doi.org/10.5465/amr.2003.10196737

Talbot, C. (2009). Public Value-The Next "Big Thing" in Public Management? International Journal of Public Administration, 32(3-4), 167-170. https://doi.org/10.1080/01900690902772059

Torfing, J. (2019). Collaborative innovation in the public sector: The argument. Public Management Review, 21(1), 1-11. https://doi.org/10.1080/14719037.2018.1430248

Twizeyimana, J. D., \& Andersson, A. (2019). The public value of E-Government - A literature review. Government Information Quarterly, 36(2), 167-178. https://doi.org/10.1016/j.giq.2019.01.001

Van Slyke, D. M. (2006). Agents or stewards: Using theory to understand the governmentnonprofit social service contracting relationship. Journal of Public Administration Research and Theory, 17(2), 157-187. https://doi.org/10.1093/jopart/mul012 
Vogelsang, I. (2002). Incentive regulation and competition in public utility markets: A 20year perspective. Journal of Regulatory Economics, 22(1), 5-27.

https://doi.org/10.1023/A:1019992018453

Wonglimpiyarat, J., \& Yuberk, N. (2005). In support of innovation management and Roger's Innovation Diffusion theory. Government Information Quarterly, 22(3), 411-422.

https://doi.org/10.1016/j.giq.2005.05.005

Yin, R. K. (2018). Case study research and applications: Design and methods. Los Angeles: Sage.

\section{Appendix}

\begin{tabular}{|c|c|c|c|c|c|}
\hline \# & Case & City & Organisation & Role of the interviewee & Duration \\
\hline 1 & A & I & $\begin{array}{l}\text { Utility } \\
\text { company }\end{array}$ & Head of marketing and sales & $65 \mathrm{~min}$ \\
\hline 2 & A & I & $\begin{array}{l}\text { Local } \\
\text { government }\end{array}$ & $\begin{array}{l}\text { Member of the city executive government and } \\
\text { member of the board of directors of the utility } \\
\text { company }\end{array}$ & $67 \mathrm{~min}$ \\
\hline 3 & A & I & $\begin{array}{l}\text { Utility } \\
\text { company }\end{array}$ & CEO & $60 \mathrm{~min}$ \\
\hline 4 & A & I & $\begin{array}{l}\text { Local } \\
\text { government }\end{array}$ & Town clerk & $76 \mathrm{~min}$ \\
\hline 5 & B & II & $\begin{array}{l}\text { Utility } \\
\text { company }\end{array}$ & CEO & $70 \mathrm{~min}$ \\
\hline 6 & B & II & $\begin{array}{l}\text { Utility } \\
\text { company }\end{array}$ & Head of telecom unit & $67 \mathrm{~min}$ \\
\hline 7 & $\mathrm{~B}+\mathrm{C}$ & II & $\begin{array}{l}\text { Local } \\
\text { government }\end{array}$ & $\begin{array}{l}\text { Secretary general of the department responsible } \\
\text { for the utility company }\end{array}$ & $61 \mathrm{~min}$ \\
\hline 8 & $\mathrm{C}$ & II & $\begin{array}{l}\text { Utility } \\
\text { company }\end{array}$ & $\begin{array}{l}\text { Person 1: Head of corporate development } \\
\text { Person 2: Digital innovation manager }\end{array}$ & $64 \mathrm{~min}$ \\
\hline 9 & $\mathrm{~B}+\mathrm{C}$ & II & $\begin{array}{l}\text { Local } \\
\text { government }\end{array}$ & Head of the office for economic development & $60 \mathrm{~min}$ \\
\hline
\end{tabular}




\begin{tabular}{|l|l|l|l|l|l|}
\hline 10 & D & III & $\begin{array}{l}\text { Local } \\
\text { government }\end{array}$ & Chief Digital Officer & 53 min \\
\hline 11 & D & III & $\begin{array}{l}\text { Utility } \\
\text { company }\end{array}$ & Head of innovation & 37 min \\
\hline 12 & D & III & $\begin{array}{l}\text { Local } \\
\text { government }\end{array}$ & $\begin{array}{l}\text { Member of the city executive government } \\
\text { (responsible for the utility company) }\end{array}$ & 59 min \\
\hline 13 & D & III & $\begin{array}{l}\text { Utility } \\
\text { company }\end{array}$ & CEO & 55 min \\
\hline 14 & D & III & $\begin{array}{l}\text { Utility } \\
\text { company }\end{array}$ & Head of telecom unit & 51 min \\
\hline 15 & D & III & $\begin{array}{l}\text { Local } \\
\text { government }\end{array}$ & Head of financial department & 53 min \\
\hline
\end{tabular}

Appendix 1. Overview of cases and interview partners. 